\title{
The Conceptual Paper on how Governance Influence the Compliance Behavior of Business Zakat Payers in Kedah
}

\author{
Yaty Sulaiman*, Maria Abdul Rahman, Nik Kamariah Nik Mat \\ Universiti Utara Malaysia, Malaysia
}

\begin{abstract}
This paper intends to further discuss the factors that influence compliance behavior of business zakat payers and the relationship between the governance of Lembaga Zakat Negeri Kedah and the compliance of business zakat payers in paying zakat. This paper begins with an introduction of zakat, discussing the meaning of zakat, the concept of business zakat, the function of zakat, the importance of zakat, followed by a brief history of Lembaga Zakat Negeri Kedah, organizational structure, and how they manage collecting and distributing zakat. Further it continues to discuss the concept of compliance behavior of business zakat payers and the concept of governance. Finally concludes the discussion including a few recommendations that can be utilized by Lembaga Zakat Negeri Kedah for further improvement.
\end{abstract}

Keywords:

Business Zakat, Governance, Compliance Behavior, Lembaga Zakat Negeri Kedah, Theory of Planned Behavior

\section{Introduction}

Zakat is crucial in a Muslim society. From the Islamic perspective, each Muslim has an obligation to pay zakat. The reason why a Muslim needs to pay zakat is to alleviate poverty, protect the poor people and needy, and to balance the country, socioeconomically (Nadzri, Rahman, Rashidah \& Omar, 2012; Hayeeharasah, Sehvises, \& Ropha, 2012; Zulfikar, 2012; Razimi, Shahril, Romle, Erdris, \& Farid, 2016; Ali, Khamar Tazilah., Shamsudin, Faisal Shukri, Nik Adelin, \& Zainol Zaman, 2017). In alQuran, the importance of zakat had been mentioned repeatedly and it illustrates that the prayers and 
zakat are aligned and interconnected, which mean both are important in the context of becoming true Muslim, they need to perform prayers five times per day and so do they need to pay zakat every year. The function of zakat in economy needs to be investigated in a broad context and not just limited to collecting and distributing zakat money conservatively (Baba, Jusoh, Muda, \& Ab Rahman, 2014; Razimi et al, 2016). Besides, zakat is one of the methods to clean Muslims wealth, to teach Muslims to live a humble life and to get blessings from Allah S.W.T. In Malaysia, collecting and distributing zakat are managed by an authorized body called State Islamic Religion Councils (SRICs). This institution plays an important role in collecting and distributing zakat money in fair and effective ways (Razimi et al, 2016).

\section{The Concept of Business Zakat}

The meaning of zakat in terms of language is; clean, holy, fertile, blessing and growing. The meaning of clean and holy in zakat terms is to cleanse the property and purify the rich from being stingy, or in other words, to get rid of the arrogant attitude of the rich. While the meaning of zakat according to sharia laws is; the issuance of a certain portion of the property, at a certain rate, given to Asnaf (individuals who are entitled to receive zakat) after fulfilling its requirements. There are two types of zakat; Zakat Fitrah and Zakat of Property (Maal). Zakat Fitrah is the type of zakat that is imposed on every Muslim each year in Ramadan, while business zakat is one of the type of Zakat of property where it is imposed on each Muslim business owner that is entitled to pay business zakat (Zulfikar, 2012).

Business zakat is compulsory to all Muslims and it is issued from business property or earnings based on manufacturing, fishing, agriculture, supply, shipping, services to trading purposes, whether in the form of personal business or partnership (fellow Muslims or non-Muslims) business, cooperative business and so on (Baba et al, 2014).

According to JAKIM (2012), a business company is obliged to pay zakat when it meets the following conditions: (1) a business is owned by Muslims, (2) a business is owned by an independent Muslim, (3) perfect ownership over the property, (4) enough Nisab (minimum amount of wealth a Muslim must have before he/she gets eligible to pay zakat), (5) enough haul (year of business must exceed one year for that company to become eligible to pay zakat, that is 354 days or 365 days according to the Islamic calendar), (6) the rate of zakat on the company is $2.5 \%$, and (7) for the partnership business between Muslims and non-Muslims, it is mandatory for Muslim partners to pay zakat based on the net income earned depending on the number of shares owned by that Muslims only.

Therefore, in Malaysia, any business engaged with Muslim people must comply with the rules and regulations as stated in sharia laws. Business zakat is very important for Muslim countries, because it helps the country to grow its economy, reduce poverty among the society and to ensure the society to have peaceful and harmonious life. The institutions that are appointed to manage zakat holds an important responsibility to carry out fair management of zakat. However, the process of collection and distribution in Malaysia still suffers from lacks in many areas, such shortcomings have arisen the issues of governance, transparency, trust, compliance of the zakat payers and etc. (Wahab and Rahim Abdul Rahman, 2011; Ahmad and Ma'in, 2014; Al Jaffri Saad, \& Wahab, \& Samsudin, 2015; Razimi et al, 2016; Haq and Abd Wahab, 2017; Ali et al, 2017). Due to the mentioned reasons, this paper intends to further discuss the governance of Zakat institutions in Kedah and compliance behavior of the business zakat payers. 


\section{Lembaga Zakat Negeri Kedah}

Lembaga Zakat Negeri Kedah (LZNK) established in 1955 by the order of his royal highness Al marhum Tengku Mahmud Ibni Al Marhum Sultan Haji Abdul Halim Muazzam Shah. This institution is responsible for governing or managing collecting zakat and distributing it to the individuals that are entitled to receive zakat as determined by the Sharia Laws. In order to ensure that the objectives and functions of LZNK are on the right path, LZNK set the vision and mission as the guidance to administrate collecting and distribution to grow fast and assist the Muslim society in Kedah to avoid poverty (Lembaga Zakat Negeri Kedah, 2018). Followings are the vision and mission of LZNK as stated in the official website of Lembaga Zakat Negeri Kedah, (2018).

\section{Vision of LZNK}

To be a catalyst for socio-economic development for Muslims especially in the state of Kedah.

\section{Mission of LZNK}

i. managing the collection and distribution of zakat truly, efficient, fair and effective through:

ii. Providing best services and facilities for payers and recipients of zakat,

iii. Collaborating with various parties,

iv. Efficient and dynamic human capital development,

v. Application of the latest technology,

vi. Improvement on the research all the time.

\section{LZNK's Organizational Structure}

Zakat Institutions in Kedah is administered by LZNK and entrusted by His Royal Highness the Sultan of Kedah, it is headed by the chief executive officer and followed by the deputy chief executive officer and assisted by seven divisions which consist of; human resources divisions, finance divisions, information technology, distribution and Asnaf development, da'wah and collection, corporate, and internal audit divisions. All positions and each of these divisions are responsible for their respective duties and are assisted by each appointed unit of the division (Lembaga Zakat Negeri Kedah, 2018).

\section{LZNK's Zakat Management System}

LZNK appointed the District Zakat Office in 12 districts in Kedah, namely Kota Setar, Kota Muda, Kulim, Kubang Pasu, Pendang, Sik, Baling, Padang Terap, Yan, Langkawi, Bandar Baru and Pokok Sena to facilitate collecting and distributing process in each district. LZNK collecting zakat via counters opened at each Distinct Zakat Office, online payments (internet banking) and professional agents appointed by LZNK. Such agents are from Management Company, Accounting Firms, Audit Firms, Law Firms, Tax Firms, Consultant Firms, Islamic Schools and also Post Office (Lembaga Zakat Negeri Kedah, 2018). In addition, LZNK also uses promotional methods to raise the awareness of zakat payers, such methods are through religious talk, sermon (khutbah), exhibition, advertisement on the billboards, radio and internet, conducting courses for Amil (zakat collectors), sending reminder letters to business owners, cooperate with MARA and private company by offering employer-friendly programs (Zulfikar, 2012).

According to Lembaga Zakat Negeri Kedah (2018), collecting zakat from business zakat in Kedah increased in 2014 to 2017, also there is a decrease in the rate in 2013 to 2014. Following are the total of business zakat collected in Kedah in five years' period. 
Table 1: Business Zakat Collected in Kedah (Lembaga Zakat Negeri Kedah, 2018)

\begin{tabular}{|l|l|}
\hline Year & Amount in Ringgit Malaysia \\
\hline 2013 & RM 29,642,222.00 \\
\hline 2014 & RM 24,898,851.00 \\
\hline 2015 & RM 25,946,191.00 \\
\hline 2016 & RM 26,098,086.00 \\
\hline 2017 & RM40,973,466.94 \\
\hline
\end{tabular}

LZNK strives to ensure that collecting zakat can be maximized and managed well, transparent and comprehensive in distributing it to those who are entitled. Zakat is distributed to eight type of individuals who are entitled to receive zakat; Fakir (those who do not have enough income for their basic needs, poor people (those who have the ability to get the necessities of life needed but still not enough), Amil (the person who is appointed to collect zakat), Muallaf (the person who has just converted to islam), Fisabillah (someone who strive to defend the religion of Allah S.W.T), Riqab (slaves or someone who has no freedom over him/herself), Gharimin (Muslims owing money to meet the basic needs of themselves but not able to pay the debt) and Ibn Sabil (Muslims who run out of money during travelling subject to Shariah Laws). Besides, distributing zakat in terms of money, LZNK also conducts some programs that can help these people such as health program, education sponsorship program, tailor training, assisting the victims of natural disasters etc. (Lembaga Zakat Negeri Kedah, 2018).

\section{The Conceptual Framework}

In the conceptual framework, the dependent variable is the compliance behavior of business zakat payers while the independent variable is the governance of Lembaga Zakat Negeri Kedah.

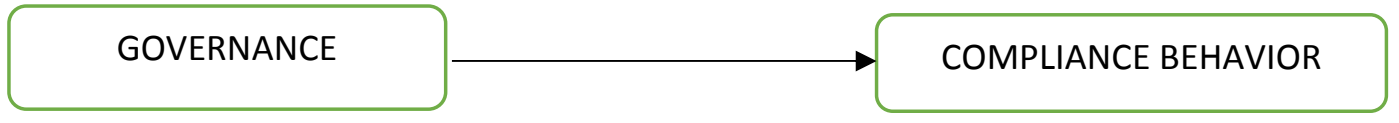

\section{LITERATURE REVIEW}

\section{The Concept of Compliance Behavior}

Compliance is the act of obeying a rule or request. In Islam, zakat is compulsory for every Muslim, they need to comply with the rules and regulations stated in Sharia Laws. In Malaysia, failure to pay any types of zakat would expose the person to fines and imprisonment. On the other hand, behavior means an action or attitude that an individual possess whether it is positive or negative towards something (Al Jaffri Saad et al, 2015).

\section{Factors Influencing Compliance Behavior among Business Zakat Payers}

In case of business zakat, business owners were investigated in view of their ability, knowledge and available resources to influence their behavior to pay zakat to zakat institutions. This investigation showed that the decision of business owners to pay zakat was influenced by the internal factors (knowledge and self-efficacy), and external factors (service quality and Interaction) that exist in the business zakat environment, where all these factors had a positive influence on business zakat compliance behavior. For instance, the knowledge of business owners regarding the method of assessment for business zakat is quite complicated to be determined, so the business owners who have knowledge about zakat pay it easier and more willing rather than those who have less knowledge about it. Self-efficacy in zakat is about how a business owner feels confident and certain about the calculation of business zakat, the higher their self-efficacy, the more likely to pay business zakat. 
Likewise, the service quality has an effect on the compliance of business zakat payer, high service quality leads to high satisfaction of its customers, therefore; it is more likely for the business zakat payers to pay zakat because they are satisfied with the service provided by zakat institutions. Same goes with interaction, business owners need to be aware and always reminded about their responsibility to pay zakat, therefore, the more interaction made between zakat institutions with the business owners, the greater the compliance of business zakat payers to pay zakat every year (Al Jaffri Saad et al, 2015).

\section{The Concept of Governance}

Governance is related to how an organization is being ruled or controlled. An organization or institution should have basic principles such as accountability, fairness, transparency and strong leadership in order to be efficient and effective. Well governed zakat institutions may contribute to the efficiency and effectiveness in zakat funds and indirectly lead to the increase of business owner's trust and compliance towards paying zakat to zakat institutions (Wahab and Abdul Rahman, 2011).

\section{Factors Influencing the Efficiency of Zakat Governance}

Muslim countries such as Malaysia have shown many drawbacks of zakat institutions, especially in managing distribution of zakat and poor governance mechanisms. The main factors that influences business' owners to pay zakat unofficially is the satisfaction of distribution and efficiency of zakat management. The results from the previous studies have proven that the feeling of satisfaction towards zakat centers' management was positively related to the payment of zakat to official institutions (Wahab and Abdul Rahman, 2011). Hasan and Mohd Shahnaz, 2005 stated that the management systems in zakat institutions influenced business owners in paying the business zakat.

Besides, lack of trust towards zakat institutions especially in the aspect of distribution transparency and inefficiency of zakat management results in non-compliance. This means that satisfaction is playing a role in determining where the zakat payment is made (Azmi, 2002; Ahmad and Ma'in, 2014). The more satisfied the business owners towards zakat institutions' management or governance, the higher the degree of compliance of business owners to pay zakat at zakat institutions (Sanep, 2003). Furthermore, Baba et al (2014), found that $45 \%$ of business zakat payers pay zakat directly to Asnaf, compared to zakat institutions (26\%) and Amil (28\%), this shows that the majority of business owners feel less confident and satisfied with the role of zakat institutions in redistributing of zakat to Asnaf.

Other than that, according to Razimi et al (2016), the efficiency of zakat institutions affected due to some reasons such as lack of human resources, outdated information communication technology (ICT), poor corporate governance, few number of branches and old and ineffective collection method.

\section{Theory of Planned Behavior}

Many previous researches have used theory of planned behavior (TPB) for their studies in determining factors that affect the compliance behavior of zakat payers for instance Kamil, 2002; Hasan and Mohd Shahnaz, 2005; Hairunnizam, Sanep, \& Mohd Ali, 2007; Al Jaffri Saad et al, 2015; Azman, 2015; Bin-Nashwan, Abdullah, \& Obaid, 2017; Ali et al,2017).

TPB was introduced by Ajzen in 1991 as a result of the study of the Reasoned Action Theory developed by Ajzen and Fishbein in 1980. In TPB, there are three factors that affect a person's behavior as the determination by their intention which are; attitude, subjective norm and perceived behavioral control. Intention is an important factor that affects people's behavior. Thus, people who 
have positive intentions on certain actions are more compliant than those who have negative intention (Ajzen \& Fishbein, 1980).

Bidin, and Azman (2013), tested TPB on their study of compliance behavior, and found out that positive attitude, subjective norm and perceived behavioral control can motivate business owners to comply with business zakat. In addition, Al Jaffri Saad et al (2015), in their findings revealed that perceived behavior control and intention are important factors in influencing behavior of business zakat compliance. The situation shows that these two factors should be taken seriously if collecting business zakat wants to be improved from time to time. Generally, intentions are a key indicator of the willingness of business owners to comply with business zakat.

\section{Recommendation}

Zakat institutions should raise awareness of Muslim societies, and not only business owners, but also their spouses and family members. Religious talks either through mass media or direct face to face lecture, zakat awareness programs and other aggressive promotions should be mobilized in a comprehensive manner so that the message of obligatory responsibility reaches the community to help increase business zakat awareness among Muslim Societies. If understanding of Muslim societies increases, it will directly influence business owners to have strong intentions to pay zakat. Furthermore, the transparency of zakat institutions in execution of collecting and distributing zakat should be taken in to account to avoid business owners from losing faith in zakat institutions. The higher society's trust on zakat institutions the more business owners will pay zakat and this will further increase collecting business zakat in the future (Al Jaffri Saad et al, 2015).

\section{Conclusion}

As a conclusion, the governance of zakat institution does affect the compliance behavior of business zakat payers. Even though collecting business zakat increases every year, but still there are many business owners who are reluctant and avoid of paying zakat. Furthermore, previous study revealed that majority of the Muslim Society are willing to pay directly to Asnaf rather than paying to zakat institution, this shows that the governance of zakat institutions still lacks trust and transparency of the zakat management in many areas (Wahab and Rahim Abdul Rahman, 2011; Zulfikar, 2012; Al Jaffri Saad et al, 2015). Thus, zakat institutions shall improve the governance and develop strategic planning to increase the awareness and the compliance of business zakat payers.

\section{Acknowledgment}

Yaty Sulaiman is Senior Lecturer of Marketing, School of Business Management, College of Business, Universiti Utara Malaysia 06010 Sintok, Kedah, Malaysia. The author would like to thank Lembaga Zakat Negeri Kedah (LZNK) and Institute Penyelidikan dan Inovasi Zakat (IPIZ)-UUM for granting this research under the Industry Research Grant Scheme and Research Innovation Management Centre (RIMC) Universiti Utara Malaysia.

\section{Reference}

Ahmad, I. H., \& Ma'in, M. (2014). The Efficiency of Zakat Collection and Distribution: Evidence from Two Stage Analysis. Journal of Economic Cooperation \& Development, 35(3).

Ajzen, I. (1991). Theory of Planned Behavior. Organizational Behavior and Human Decission Processes, 50: 179-221.

Ajzen, I., \& Fishbein, M. (1980). Understanding Attitudes and Predicting Social Behavior. Englewood Cliff, NJ: PrenticeHall. Fishbein, M., Jaccard, J., Davidson, A. R., Ajzen, I., \& Loken, B. (1980). Predicting and understanding family planning behaviors. In Understanding attitudes and predicting social behavior. Prentice Hall. 
Al Haq, M. A., \& Wahab, N. B. A. (2017). Effective Zakat Distribution: Highlighting Few Issues and Gaps in Kedah, Malaysia. Al-Iqtishad: Jurnal Ilmu Ekonomi Syariah, 9(2), 259-288.

Ali, M. A. M., Khamar Tazilah, M. D. A. B., Shamsudin, A. I. B., Faisal Shukri, F. R. B., Nik Adelin, N. M. F. A. B., \& Zainol Zaman, W. M. S. B. (2017). Factors that influence the zakat collection funds: A case in Kuantan. SEAJBEL 13, no. $1,30-37$.

Al Jaffri Saad, R., \& Wahab, M. S. A., \& Samsudin, M. A. M. (2015). Factors Influencing Business Zakah Compliance Behavior among Moslem Businessmen in Malaysia: A research Model. Kuala Lumpur, Malaysia. Saad, R. A. J., Wahab, M. S. A., \& Samsudin, M. A. M. (2016). Factors Influencing Business Zakah Compliance Behavior among Moslem Businessmen in Malaysia: A Research Model. Procedia-Social and Behavioral Sciences, 219, 654-659.

Azman, F. M. N., \& Bidin, Z. (2015). Factors influencing Zakat Compliance Behavior on Saving. International Journal of Buiness and Social Research, 5(1), 118-128.

Baba, Z. S., Jusoh, H., Muda, H., \& Ab Rahman, S. M. A. S. (2014). Tanggapan usahawan terhadap zakat perniagaan berbanding cukai pendapatan di Terengganu. Jurnal islam dan Masyarakat kotemporari, 3, 97-113.

Bidin, Z., M.Z. Othman and F.M.N. Azman. (2013). Zakah Compliance Intention Behaviour on Saving among Universiti Utara Malaysia's Staff. Malaysia.

Bin-Nashwan, S. A., Abdullah, N. S., \& Obaid, M. M. (2017). A REVIEW OF LITERATURE IN MANAGEMENT CONTROL SYSTEM (MCS), BUSINESS STRATEGY, AND FIRM'S PERFORMANCE. International Journal of Management Research and Reviews, 7(2), 99.

Hairunnizam, W., Sanep, A., \& Mohd Ali, M. N. (2007). Kesedaran Membayar Zakat Pendapatan di Malaysia. Islamiyyat, 29, 53-70. Wahid, H., Ahmad, S., \& Noor, M. A. M. (2007). Kesedaran membayar zakat pendapatan di Malaysia. Islamiyyat, 29(1), 53-70.

Hasan, B., \& Mohd Shahnaz, S. (2005). Kajian terhadap faktor yang mempengaruhi pembayaran zakat perniagaan di kalangan usahawan: Kes kajian Terengganu. In Seminar Ekonomi dan Kewangan Islam, ESSET Bangi, Selangor.

Haq, A., Ashraf, M., \& Abd Wahab, N. B. (2017). Effective Zakat Distribution: Highlighting Few Issues and Gaps in Kedah, Malaysia. Al-Iqtishad: Jurnal Ilmu Ekonomi Syariah, 9(2), 259-288.

Hayeeharasah, F., Sehvises, S., \& Ropha, H. (2012). The Timeline of Zakah. Procedia-Social and Behavioral Sciences, 88, 7. Hayeeharasah, F., Sehvises, S., \& Ropha, H. (2013). The Timeline of Zakah. Procedia-Social and Behavioral Sciences, 88, 2-7.

JAKIM (2012). Keputusan Muzakarah Jawatankuasa Fatwa Majlis Kebangsaan Bagi Hal Ehwal Ugama Islam Malaysia, Putrajaya: JAKIM. Malaysia, J. K. I. (2009). Keputusan Muzakarah Jawatankuasa Fatwa Majlis Kebangsaan Bagi Hal Ehwal Ugama Islam Malaysia. PutraJaya: JabatanKemajuanIslam Malaysia.

Kamil, M., I. (2002). Gelagat Kepatuhan Zakat Pendapatan Gaji di Kalangan Kakitangan Awam. Universiti Utara Malaysia, Sintok. Kamil, M. (2002). Gelagat kepatuhan zakat pendapatan gaji di kalangan kakitangan awam persekutuan Negeri Kedah (Doctoral dissertation, Universiti Utara Malaysia).

Lembaga Zakat Negeri Kedah, (2018). Info, Profil dan Statistik Kutipan Zakat. Retrieved from http: www.zakatkedah.com.my

Nadzri, F. A. A., Rahman, A., \& Rashidah \& Omar, N. (2012). Zakat and Poverty Alleviation: Roles of Zakat Institutions in Malaysia. International Journal of Arts and Commerce, 1(7), 61-72.

Razimi, A., Shahril, M., Romle, A. R., Erdris, M., \& Farid, M. (2016). Zakat management in Malaysia: A review. AmericanEurasian Journal of Scientific Research, 11(6), 453-457.

Sanep, A. (2006). Zakat Syarikat Perkongsian: ke atas Entity Syarikat atau Individu. Pensyariatan, Perekonomian dan Perundangan. Bangi, Selangor. 164-173.

Wahab, N. A., \& Rahim Abdul Rahman, A. (2011). A framework to analyse the efficiency and governance of zakat institutions. Journal of Islamic Accounting and Business Research, 2(1), 43-62.

Zulfikar. (2012). Pengurusan Zakat dalam Rangka Pembasmian Kemiskinan di Kota Setar Kedah Darulaman (Doctoral dissertation, Universiti Utara Malaysia). 


\section{APPENDIX}

CARTA ORGANISASI

LEMBAGA ZAKAT NEGERI KEDAH

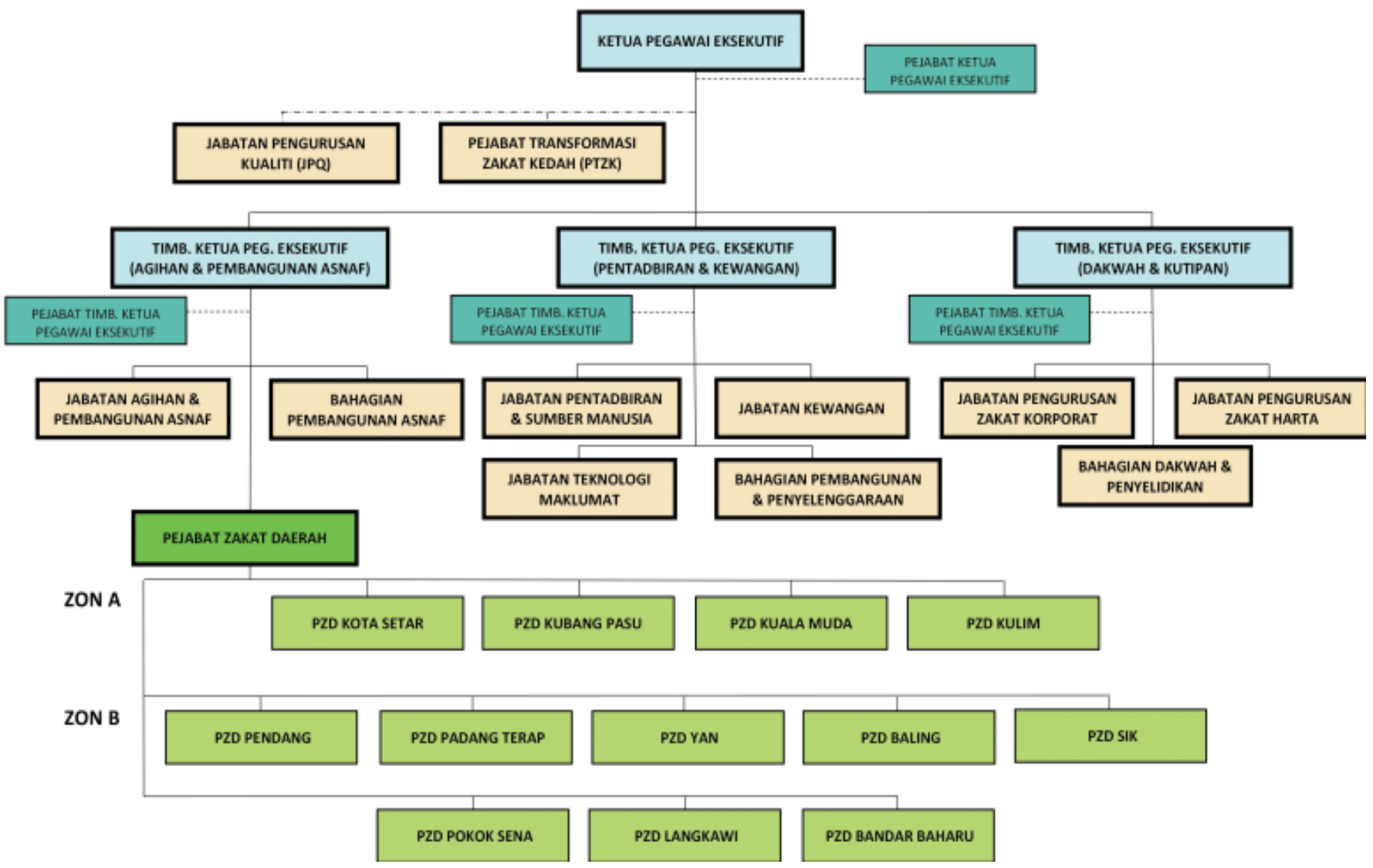

Figure 1: Organizational Structure of LZNK (Source: www.zakatkedah.com.my) 


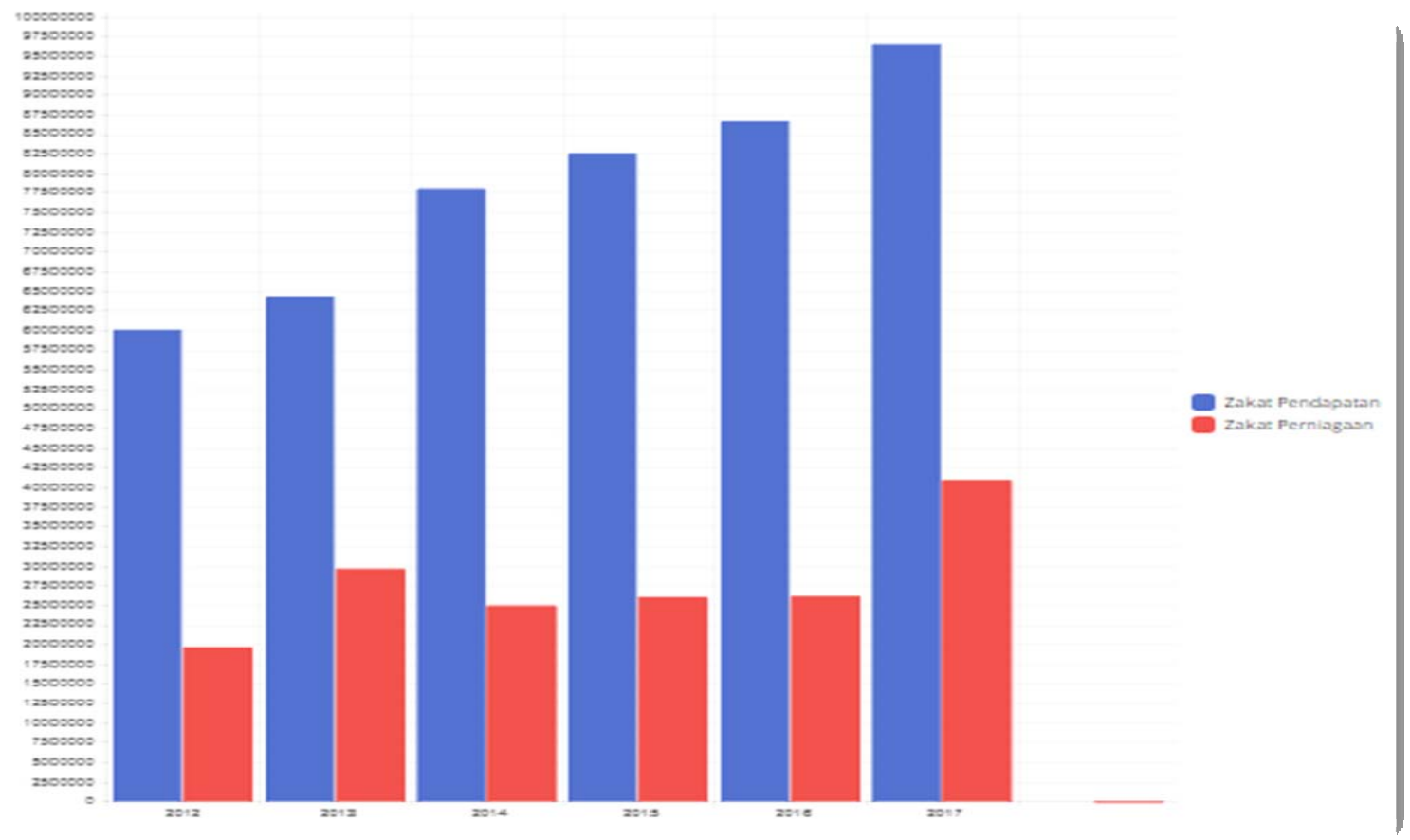

Figure 2: Business Zakat Collection by LZNK (Source: www.zakatkedah.com.my) 